\title{
Vagtskifte i Beijing
}

\section{Stig Thøgersen}

\section{Kinesisk politik er blevet mere regelbundet, men spillet om at vælge ledere er ikke blevet meget mere gennemsigtigt og foregår stadig bag lukkede døre uden folkelig indflydelse}

Da Hu Jintao besøgte Danmark i juni 2012, var det ved at være sidste udkald, hvis vi skulle nå at se ham, mens han stadig er Kinas mægtigste mand.

Hu kom hertil i sin egenskab af præsident, men det er faktisk kun et bijob for ham. Hans egentlige magtposition ligger i posten som generalsekretær for Kinas Kommunistiske Parti (KKP), og den post træder han tilbage fra på den 18. nationale partikongres, som vil blive afholdt i efteråret 2012. I foråret 2013 vil han så gå af som præsident, og den 12. Nationale Folkekongres vil vælge hans efterfølger. Den nuværende regeringsleder, premierminister Wen Jiabao, vil blive udskiftet samtidig, og dermed vil Hu og Wens fælles tiårige styre formelt være afsluttet, selv om de nok begge vil fortsætte med at trække i trådene i nogle år endnu.

Forudsigeligheden i hele magt- skiftet fortæller meget om, hvor institutionaliseret og regelbundet kinesisk politik på nogle måder er blevet. Den politiske proces er inddelt i moduler på fem år, som er den periode, som både parti- og folkekongressen bliver valgt for. Ligesom sin forgænger, Jiang Zemin, har Hu nu siddet $\mathrm{i}$ to fulde perioder, og hans efterfølger, Xi Jinping, er for længst kørt i stilling. Der er ikke længere nogen suveræn leder i klasse med Mao Zedong eller Deng Xiaoping, der i kraft af sin personlige magt og prestige kan udpege sin efterfølger og evt. skille sig af med ham igen efter forgodtbefindende.

Alligevel er spillet om udvælgelsen ikke blevet ret meget mere gennemsigtigt. Udpegningen af ledere foregår stadig bag lukkede døre uden folkelig indflydelse. Formelt er det Partikongressen, der vælger generalsekretæren, og Folkekongressen, der vælger præsidenten og pre- 


\section{BAGGRUND}

mierministeren, men det er mest en formalitet, der skal give politisk legitimitet. Den reelle udpegning af nye ledere foregår inden for partitoppen i en trinvis proces, hvor en bredere kreds bliver hørt, og hvor de nye folk gennemgår en årelang målrettet træning og afprøvning i forskellige typer af politiske lederjob, inden de når topposterne.

Som jeg vender tilbage til senere, kom der for nylig en håndfuld grus $\mathrm{i}$ maskineriet, da en af de mest markante skikkelser i den nye generation, Bo Xilai, pludselig blev involveret i nogle sager, der gjorde det muligt for hans modstandere af få skovlen under ham. Men bortset fra dramaet omkring Bo ser magtskiftet ud til at køre som planlagt.

\section{Hu og Wen stempler ud}

I denne artikel ser jeg først på, hvad $\mathrm{Hu}$ Jintao og Wen Jiabao har udrettet i løbet af de ti år, de har haft magten, og på den politiske model, de har (videre) udviklet. Derefter præsenterer jeg $\mathrm{Hu}$ og Wens forventede arvtagere som Kinas ledere, Xi Jinping og Li Keqiang og en enkelt af de mange udfordringer, de står overfor, nemlig de holdningsmæssige ændringer blandt unge kinesere. Artiklens fokus vil være på indenrigspolitikken snarere end på Kinas internationale relationer, som er et emne, der fortjener en selvstændig behandling.

$\mathrm{Hu}$ Jintao er langt fra nogen karis- matisk leder. Hans måde at gribe statsbesøget i Danmark an var karakteristisk for hans generelle stil: Ingen pressemøder med risiko for kritiske spørgsmål, ingen direkte kontakter med befolkningen og ingen udtalelser, der går ud over det strengt formelle og almindelige. På kommunikationsfronten bestod det mest sprælske indslag i hele hans regeringsperiode i et meget kortvarigt eksperiment i juni 2008, hvor han i nogle minutter chattede med brugerne af et internetforum, der hører under partiavisen Folkets Dagblad.

Jeg har endnu til gode at høre en kineser udtrykke nogen form for begejstring over $\mathrm{Hu}$, selv om han høster udbredt anerkendelse for sine resultater. Vi er så langt fra Mao-tidens persondyrkelse, som man overhovedet kan komme.

Hans højre hånd, premierminister Wen Jiabao, har et noget bedre image i befolkningen. Det er ham, der har taget ud og besøgt katastrofeområder og hårdt ramte familier, som fx i 2011 hvor han besøgte ofrene for den store togkatastrofe nær Wenzhou, eller endnu mere markant i 2008 hvor han meget hurtigt efter det ødelæggende jordskælv i Sichuan fløj til det ramte område og på den måde demonstrerede topledelsens medfølelse. Han er kendt for at bryde ud i gråd ved særligt følelsesladede lejligheder, og nogle kinesere finder ham hyklerisk, men han har bestemt også tilhængere, der omtaler ham som bedstefar Wen 
og betragter ham som en retskaffen leder.

Politisk har Wen flere gange luftet $\varnothing n s k e r$ om at gennemføre politiske reformer i demokratisk retning, og han bliver opfattet som forholdsvis liberal, uden at det dog har ført til grundlæggende forandringer i det politiske system.

\section{Ikke de store reformatorer}

$\mathrm{Hu}$ og Wen vil ikke blive husket som store reformatorer i stil med Deng Xiaoping og de andre i den generation, der i 1980'erne og 1990'erne stod for Kinas dristige omstillingsproces fra planøkonomi og statsstyring til et mere markedsbaseret system med staten i en regulerende rolle. Men de har formået at holde sammen på nationen og fastholde KKP's magtposition igennem et helt årti, hvor Kinas økonomiske vækst er fortsat med at buldre fremad, og det er i sig selv en kraftpræstation.

Da de overtog magten, stod det allerede klart for hele verden, at Kina var på vej til at blive en økonomisk supermagt, men man talte stadig mest om det som et fremtidsscenarium. Under deres tiårsperiode har Kina haft en stabilt høj økonomisk vækst, så landet nu er verdens næststørste økonomi og største eksportør. Og hele verden ser mod Kina, når man skal prøve at skimte en vej ud af den økonomiske krise.

De har således først og fremmest bidraget med politisk stabilitet. Det betyder ikke, at alt har været fred og fordragelighed i det kinesiske samfund. Der har hvert år været titusindvis af protester og demonstrationer blandt utilfredse bønder, arbejdsløse, pensionister, etniske minoriteter og andre, der har følt sig tilsidesat eller kørt over af den rivende udvikling, men styret har formået at isolere protesterne og undgå, at der er opstået en mere samlet og organiseret opposition.

Imens er økonomien fortsat med at drøne fremad, infrastrukturen er blevet udbygget markant, og enorme byggeprojekter har forvandlet byerne til uigenkendelighed.

\section{Det harmoniske samfund?}

Hu og Wen har navngivet deres primære politiske projekt 'det harmoniske samfund', og især Hu Jintao ser formodentlig dette begreb som sit væsentligste bidrag til Kinas politiske ideologi. Det med harmonien skal ses på baggrund af, at Kina under Hus forgængere var ved at blive et ekstremt polariseret land med voldsomme økonomiske forskelle mellem rige og fattige, mellem land og by og mellem velhavende kystområder og tilbagestående indlandsprovinser. For at bevare den sociale stabilitet har $\mathrm{Hu}$ og Wen forsøgt at afbøde de værste virkninger af ulighederne.

Omkring tiden for deres magtovertagelse i 2002 og 2003 var der især politisk fokus på landområder- 
ne, hvor der var mange og ofte voldsomme protester mod korrupte lokale ledere, vilkårlig opkrævning af skatter og afgifter og beslaglæggelser af jord uden rimelig kompensation. Efter nogle tilløb afskaffede ledelsen så landbrugsskatten i 2006, en reform der havde stor symbolsk værdi, og som var populær ude i landsbyerne.

Igennem hele Folkerepublikkens historie har landområderne betalt for industrialiseringen og for byboernes højere levestandard, og også i kejsertiden var landbrugsskatten en hovedkilde til finansiering af offentlige udgifter, så det var en beslutning af historiske dimensioner, da den endelig blev afskaffet.

I første omgang førte reformen primært til, at landsbyer og kommuner mistede en vigtig indtægtskilde og derfor måtte opgive at gennemføre større kollektive projekter, men senere er der kommet målrettede centrale investeringer i stedet, og rapporter tyder på, at pengene nu, formentlig for første gang i historien, flyder fra byerne ud i landområderne i stedet for omvendt. En anden vigtig reform for landsbyboerne har været afskaffelsen af uddannelsesafgifter for de ni obligatoriske år i grund- og mellemskolen, en udgift som især tyngede bønderne på grund af deres langt lavere disponible indkomster.

Protesterne på landet er ikke ophørt, men det er tyndet ud i dem, og det virker som om den opdæm- mede vrede, der var en grundstemning omkring årtusindskiftet, er blevet dæmpet en del.

$\mathrm{Hu}$-Wen-administrationen har også arbejdet på opbygningen af en form for socialt sikkerhedsnet, der primært er baseret på forsikringsprincippet. Da man afskaffede kollektiverne på landet og de sociale goder, der var knyttet til ansættelse i en statsejet virksomhed, stod store dele af befolkningen nærmest forsvarsløse over for sociale begivenheder som arbejdsløshed, alvorlig sygdom og alderdom.

Den sociale dækning er stadig på et lavt niveau sammenlignet med $\mathrm{fx}$ Vesteuropa, men de fleste i byerne har nu en sundhedsforsikring, og også i landområderne har man fra 2003 etableret en kollektiv sundhedsforsikring, som dækker en vis del af de forsikredes udgifter ved besøg på klinikker og hospitaler. For virksomhedernes ansatte er der indført sygeforsikring, arbejdsløshedsforsikring, forsikring mod arbejdsskader, pensionsforsikring og en barselsordning. En stor lov om social sikkerhed fra 2011 skabte en samlet lovgivningsmæssig ramme om alle disse tiltag. Desuden er der indført en form for socialhjælp til de allerfattigste, som kan være et middel til at dæmpe social utilfredshed udløst af ren desperation.

Ud over at lægge en dæmper på social uro er forsikringsordningerne også tænkt som et vigtigt middel til at øge privatforbruget, da mange ki- 
nesiske familier har følt sig nødsaget til at spare op til uforudsete hændelser i stedet for at bruge pengene på forbrugsgoder.

Da Kina ikke siden år 2000 har offentliggjort officielle målinger af gini-koefficienten, den internationalt mest udbredte målestok for økonomisk ulighed, er det svært at sige, hvad reformerne har betydet for fordelingspolitikken. Den officielle begrundelse for de udeblevne tal er, at der er så mange uklarheder omkring, hvad især de rigeste kinesere faktisk tjener, at man ikke kan komme med realistiske beregninger. De 'grå' indtægter er simpelthen for store. Men der er næppe tvivl om, at tavsheden også skyldes et vist politisk ubehag ved udviklingen.

\section{Fra 'made' til 'created' in China}

Undersøgelser fra Kinas Samfundsvidenskabelige Akademi, en officiel tænketank, skønnede at gini-koefficienten i slutningen af 00 'erne lå på omkring 0.47 , og det placerer i international målestok Kina som et land, der stadig har en meget stor grad af ulighed. Kinas Statistik har lovet at offentliggøre nye officielle tal for uligheden i 2013, som så vil kunne bruges til at gøre regnskabet for Hu og Wens årti op på den front.

Et andet centralt projekt for $\mathrm{Hu}$ og Wen har været at omstille Kina fra en rolle som hele verdens fabrik til et innovativt og kreativt samfund, hvor der sker en høj grad af værdi- forøgelse. Projektet blev påbegyndt allerede af Kinas leder i den foregående tiårsperiode, Jiang Zemin, der så fremtidens internationale kappestrid som en kamp om de skarpeste hjerner, der kan designe og skabe den slags produkter, som man virkelig kan tjene penge på. Kineserne skulle ikke længere være henvist til at sidde til en latterlig lav løn og producere løbesko, der senere blev solgt for skyhøje priser til glæde for det multinationale selskab, der ejede varemærket.

Hu og Wen har fulgt op på Jiangs planer med en satsning på, at Kina i fremtiden skal have en større del af kagen ved at udvikle sine egne stærke og respekterede brands og højteknologiske produkter. Denne strategi er blevet understøttet af massive og målrettede investeringer i forskning og uddannelse. Danske forskere kan godt blive misundelige, når de ser det udstyr og hører om de bevillinger, som deres kinesiske kolleger har til rådighed. Tydeligst er udviklingen måske, hvis man ser på studenteroptaget på de videregående uddannelser. I år 2000 blev der i Kina optaget 5,6 millioner studerende.

Ti år senere, i 2010, blev der optaget 22,3 millioner eller fire gange så mange. Selv om man kan stille spørgsmålstegn ved kvaliteten af nogle af de nye universiteter og colleges, er der ingen tvivl om, at det generelle uddannelsesniveau blandt yngre kinesere er steget betydeligt 
under $\mathrm{Hu}$ og Wen. Ekspansionen har ikke kun været drevet frem oppefra. Næsten alle kinesiske familier har en drøm om, at deres børn skal klare sig godt i den hårde konkurrence i skolen og ende med at få en universitetsuddannelse, så der har været et stort folkeligt pres på staten for at udvide kapaciteten.

Et andet træk i kampen om hjernerne har været at tilbyde generøse velkomstpakker til kinesiske topforskere, der har studeret i udlandet, hvis de vender tilbage til fædrelandet. Mange af de hjemvendte har fået centrale poster i forskning og uddannelse, og der er også ansat flere udlændinge på topuniversiteterne. Især inden for de naturvidenskabelige og tekniske fag er der ingen tvivl om, at Kina under Hu og Wen er blevet en sværvægter også inden for forskning og udvikling med klart fokus på de områder, der bliver afgørende for fremtidens globale økonomi, som fx energi og miljø, bioteknologi osv.

Omstillingen til et kreativt og innovativt samfund er dog også løbet ind i nogle problemer. På uddannelsesområdet er det stadig det meget konkurrencebetonede eksamenssystem, der svinger taktstokken, så på trods af en masse propaganda om, at der skal være mere plads til individualitet, kreativitet og selvstændig læring i skolerne, er elevernes dagligdag fortsat præget af udenadslæren og terperi, og især de unge fra middelklassen er under konstant pres fra forældre og skole for at præstere. Det kan være svært at være kreativ og tænke 'ud af boksen' under de vilkår.

Samtidig har den voldsomme vækst $i$ antallet af universitetsstuderende ført til en overproduktion af bachelorer, som går direkte ud i arbejdsløshed, hvilket er et ekstra stort problem i et land, hvor mange forældre må låne hos venner og familie for at finansiere deres barns universitetsuddannelse. De nyuddannede er ofte villige til at acceptere meget lavere lønninger, nogle gange lavere end hvad man byder ufaglærte migrantarbejdere, og det har skabt en ny, højtuddannet underklasse i byerne, som potentielt kan være en trussel mod den sociale stabilitet.

Men overordnet set er der ingen tvivl om, at Kina er bedre forberedt på at tage det næste trin op ad den globale økonomis værdistige, end da $\mathrm{Hu}$ og Wen overtog magten.

\section{Ikke parlamentarisk demokrati}

Mens økonomien har fortsat sin vækst, har det mildest talt ikke været et stort årti for politiske reformer. Den officielle kinesiske retorik siger noget i retning af, at demokrati er en udmærket ting, men det skal ikke ligne det 'vestlige' flerpartisystem, og det skal under ingen omstændigheder indføres lige med det første. Det mest demokratiske element i det nuværende system er stadig landsbyvalgene, som efter en 
længere forsøgsperiode blev indført på nationalt plan under Jiang Zemin. Her kan landsbyboere vælge deres egne ledere gennem forholdsvis åbne valg med flere kandidater. Modellen er blevet gradvist udviklet siden 1980'erne, og den bliver stadig mere institutionaliseret og finpudset.

Under Hu og Wen har man fået nogle lignende valg til beboerkomiteer i byområderne, men disse organer har begrænset politisk betydning, da de ikke råder over særlig mange ressourcer eller magtbeføjelser.

Alle andre forsøg på demokratisering er til gengæld blevet banket grundigt ned. Der har været eksperimenteret lidt med valg af ledere på kommunalt niveau, dvs. på niveauet over landsby- og beboerkomiteer, men ideen har ikke fået lov til at sprede sig. Der er også enkelte uafhængige kandidater, der har stillet op til de lokale folkekongresser i kommuner og amter, hvor medlemmerne i princippet er direkte valgt.

Selv om disse kongresser har meget begrænset indflydelse, har KKP altid insisteret på at beholde den fulde kontrol over, hvem der bliver valgt ind. Især ved valgene i 2011 var der en del uafhængige kandidater, der stillede op, fordi de gennem blogs på internettet havde fået en mulighed for at samle tilhængere uden om de statskontrollerede kanaler, men langt de fleste blev hurtigt neutraliseret af de allestedsnær- værende partimyndigheder, og de er ikke kommet til at spille nogen betydende rolle i det politiske liv.

Hu Jintao har også ført en hård kurs mod protester fra etniske mindretal og politiske dissidenter. I slutningen af 1980'erne, som et skridt på vejen til at blive national leder af KKP, var Hu partileder i Tibet, hvor han slog voldsomt ned på tibetanske demonstranter i foråret 1989, så det er ikke uventet, at han også i sin tid som topleder har været kompromisløs på det felt. Fremtrædende demokratiaktivister som fx Nobelprisvinderen Liu Xiaobo og mange advokater, der har forsvaret anklagede i politiske retssager, er ligeledes blevet forfulgt og fængslet.

Samtidig har KKP kæmpet en hård - om end delvis forgæves kamp for at få kontrol over internettet og de mange muligheder, det tilbyder til dem, der ønsker at kritisere styret. Så det er ikke ligefrem demokratiske fremskridt, der har præget Hu-Wen-æraen.

\section{Hvilken politisk model?}

Fraværet af demokratiske valg og undertrykkelsen af oppositionelle kræfter betyder dog ikke, at Kinas politiske liv har stået stille. I løbet af Hus og Wens årti har der tegnet sig omridset af en model, der bygger på udvidede konsultationer med forskellige samfundsmæssige grupperinger. Det er en form for pluralisme uden demokrati, og det er svært 
at vide, om det vil udvikle sig til en mere permanent model, eller om det er led i en overgang til et mindre autoritært styre.

Politologer har længe talt om, at Kina har et fragmenteret autoritært styre. Det betyder, at politiske beslutninger sjældent tages af et enigt og samlet magtapparat. De er snarere resultatet af kampe mellem forskellige interesser, der ofte er repræsenteret af de enkelte sektorer i administrationen. Skal der fx bygges en dæmning, vil energisektoren prøve at fremme projektet, fordi det kan øge produktionen af elektricitet, mens landbrugssektoren vil gå imod, fordi landbrugsjord vil gå tabt. Der kan være mange både nationale og lokale interessenter i disse beslutninger, som alle vil prøve at påvirke de endelige beslutningstagere, og selve beslutningen afgøres så af interessenternes relative bureaukratiske styrke og af deres pressionsmidler.

I løbet af de sidste årtier er kredsen af spillere i denne proces blevet udvidet. Der er kommet ngo'er på banen, som har påvirket udfaldet af fx miljøsager og spørgsmål om forbrugerbeskyttelse. Der er også kommet kritiske medier, der kan skabe deres egen dagsorden ud fra et socialt og politisk engagement, som man $\mathrm{fx}$ har set i sager om korruption og magtmisbrug, men også i miljøspørgsmål og i sager, hvor tvivlsomme retslige afgørelser er blevet kritiseret og omgjort.
Dertil kommer forskellige repræsentanter for erhvervsinteresser, der indgår i meningsudvekslinger med statens repræsentanter. Selv de normalt temmelig bovlamme folkekongresser er begyndt at blande sig i formulering og lokal implementering af lovgivningen. Politiske beslutninger påvirkes således af langt flere aktører end tidligere.

Også almindelige borgere kan få en vis indflydelse. Et af de mest nyskabende forsøg i Kinas politiske liv handler om, at man lader tilfældigt udvalgte borgere træffe beslutninger under vejledning af eksperter. Det kan $\mathrm{fx}$ handle om at prioritere mellem forskellige anlægsprojekter i et lokalområde. Skal byen have en ny omfartsvej, eller er det vigtigere at få renset spildevandet, eller måske at anlægge en park? Borgerne får præsenteret mulighederne af indkaldte eksperter og diskuterer dem derefter i grupper, hvor deltagerne også kan trække på eksperternes viden. Til sidst er der en afstemning, og byens folkekongres vil så føle sig forpligtet til at følge flertallets indstilling.

Metoden er inspireret af ideer om deliberativt demokrati, og den praktiseres stadig kun få steder, specielt i den velstående provins Zhejiang $\mathrm{i}$ $\varnothing$ stkina. Den bliver dog positivt omtalt i den officielle presse, så det er ikke utænkeligt, at den vil få lov til at brede sig.

Herudover er partistaten begyndt at interessere sig mere for, hvad bor- 
gerne mener. Der er oprettet meningsmålingsinstitutter i alle provinser, som følger folkestemningen tæt og rapporterer videre til den politiske ledelse. Man følger også med i de kritiske debatindlæg på blogs og i debatfora, ikke kun for at undertrykke oppositionelle meninger, men lige så meget for at kunne opspore, hvilke problemer befolkningen er bekymret over. På den måde håber man at kunne udbedre skaderne og komme sociale protester i forkøbet. Der er ligeledes etableret forskellige muligheder for at indberette korruption og magtmisbrug, igen for at kunne luge ud i egne rækker og undgå folkelig utilfredshed.

Disse forskellige redskaber bruges langt fra konsekvent, og mange steder kører man videre på den gamle enevældige facon.

\section{Hvem er de nye ledere?}

Men hvis man skal anlægge et optimistisk syn på demokratiets fremtid i Kina, kan man begynde at skimte omridsene af en politikopfattelse, hvor KKP stadig definerer sig selv som det alvidende magtcentrum, der har ret til at træffe beslutninger på hele nationens vegne, men hvor man i højere grad inddrager borgernes synspunkter i beslutningsgrundlaget og måske, måske, lægger enkelte afgørelser ud til direkte afstemning.

Spillet om hvem der skal overtage den arv, som Hu og Wen efterlader sig, har været i gang længe, og en hel generation af politikere født $\mathrm{i}$ 1950 'erne står parat. I første omgang handler det om at komme ind i det kommunistiske partis politbureau, der har 25 medlemmer, og, endnu mere afgørende, i dets stående udvalg, der udgør magtens inderste kreds. Der er ingen udenlandske iagttagere, der ved præcist, hvad der foregår i udvalget, men man regner med, at der skal være en høj grad af konsensus inden for gruppen ved alle større beslutninger.

Udvalget har for tiden ni medlemmer, men størrelsen er ikke bundet af regler, så man kan i princippet godt vedtage at udvide kredsen i forbindelse med de store udskiftninger, der skal ske i efteråret 2012. Udvælgelsen af medlemmer til både politbureau og stående udvalg er helt uigennemsigtig og baseret på en lang række kompromiser mellem de forskellige grupperinger og magtfulde personlige netværk.

Det er i denne sammenhæng, man skal se den største skandale inden for topledelsen i de sidste mange år, nemlig Bo Xilais fald i foråret 2012. Bo var medlem af politbureauet, og det er almindeligt antaget, at han prøvede at blive valgt ind i det stående udvalg. Hans måde at gøre det på var imidlertid kontroversiel.

Han forsøgte sig med noget helt usædvanligt for en kinesisk topleder, nemlig at tegne en selvstændig politisk profil, der appellerede direkte 
til menige kinesere. Som leder af kæmpebyen Chongqing førte han spektakulære kampagner mod organiseret kriminalitet og korruption. Han prøvede også at fremme en 'rød kultur' med rødder tilbage til Kulturrevolutionen og blev generelt set som en repræsentant for 'det nye venstre' i kinesisk politik, selv om langt fra alle hans økonomiske tiltag pegede i den retning.

Det er svært at måle politisk popularitet i Kina, men mange rapporter tyder på, at Bos synspunkter havde god klangbund i Chongqings befolkning. Det har imidlertid ikke været populært i Beijings inderkreds, at han prøvede at overhale konkurrenterne ved at skaffe sig folkelig opbakning. Hugget faldt i marts i år i forbindelse med en virkelig spektakulær sag, hvor en af Bos underordnede prøvede at hoppe af til det amerikanske konsulat i nabobyen Chengdu.

Sagen involverer bl.a. anklager om, at Bos hustru har myrdet en engelsk forretningsmand, så den indeholder alle ingredienserne til en politisk thriller. Bos fald bliver set som en sejr for Wen Jiabao og den mere liberale fløj i partiet.

Med mindre der sker lignende sensationer hen over sommeren og efteråret, skulle der nu være klar bane for, at Xi Jinping (udtales ca. Sji Djinping) kan udnævnes til generalsekretær for KKP på efterårets partikongres og senere til præsident efter $\mathrm{Hu}$, mens Li Keqiang (udtales ca. Li Kørtjang) ligger til at blive ny premierminister efter Wen. Xi er født i 1953 og Li i 1955, så de har begge, hvad der anses for at være en passende alder for disse poster, lige som de begge har bevist deres driftsikkerhed som provinsledere.

Det er svært at sige, hvad de to står for rent politisk. Kinesiske ledere på vej mod toppen har sjældent fordel af at være alt for markante i deres udmeldinger, men iagttagere placerer dem i hver sin fraktion, uden at det dog behøver betyde, at de er politisk uenige. Fraktionerne handler sandsynligvis ofte mere om personlige netværk end om politiske forskelle.

Xi Jinping tilhører kredsen af 'små prinser', som man kalder medlemmerne af Kinas politiske aristokrati. Hans far var en kommunistisk veteran, som besad høje poster både før og efter Kulturrevolutionen, hvor han blev udrenset men senere rehabiliteret. Denne baggrund deler han med fx Bo Xilai og mange andre politiske ledere i denne generation, og nogle politiske iagttagere opfatter dem som en fraktion, selv om de ikke nødvendigvis er enige om alt.

I den kinesiske offentlighed er Xi mest kendt for at være gift med en berømt kinesisk sangerinde, hvis musikalske karriere nok må sættes på stand by, når Xi rykker helt til tops. Han har en baggrund som kemiingeniør, og de udlændinge, der har mødt ham, betegner ham som 
en ligefrem og pragmatisk type, men ingen tør komme med et bud på, hvor han vil føre Kina hen rent politisk.

Den formodet kommende premierminister, Li Keqiang, er ikke på samme måde født til magt, men har benyttet sig af en anden vigtig karrierevej nemlig den kommunistiske ungdomsliga, som siges at danne grundlag for en anden hovedfraktion. Li har, i lighed med Hu Jintao, været generalsekretær for ungdomsligaen og har mange værdifulde forbindelser fra den tid. Hvor stort set hele $\mathrm{Hu}$ og Wens generation af ledere har en ingeniørbaggrund, har Li studeret jura og økonomi, og han har især haft ansvar på det økonomiske område.

Det siges, at han har en særlig interesse for områder som ren energi og klimaforandringer, men også for at forbedre det offentlige sundhedssystem og fødevaresikkerheden, som har været under stærk kritik.

\section{Det fremtidige politiske system}

Netop omkring lederskift bliver det tydeligt, hvor lidt vi egentlig ved om mekanismerne i kinesisk elitepolitik. De vigtigste personvalg træffes stadig for nedrullede gardiner af mennesker, som hverken den kinesiske eller den internationale offentlighed præcist ved hvem er, og på baggrund af dagsordner og loyaliteter, som man som regel kun kan gætte sig til. Hvor længe dette system kan opretholdes, kan man kun gisne om.

Som nævnt ovenfor er der ikke meget der tyder på, at ledelsen selv går rundt med tanker om store politiske reformer, men ændringerne kan komme andre steder fra. Her kan det være interessant at kigge på et aspekt af udviklingen, som normalt ikke får megen opmærksomhed i demokratiseringsdiskussionen, nemlig de mentale ændringer, der sker blandt Kinas unge generation som følge af landets omstilling til en mere innovativ økonomi.

Da jeg for nylig interviewede unge kinesere bl.a. om deres forestillinger om fremtiden, oplevede jeg ikke, at de specielt efterspurgte en form for politisk demokrati, hvor de kan gå hen og sætte kryds ud for et politisk parti hvert fjerde år. Derimod var det tydeligt, at de ønskede en højere grad af personlig frihed og et liv, som i mindre grad var styret af autoriteter.

Som nævnt tidligere er Kinas plan om at omstille sig til en mere innovativ og værdiskabende form for produktion blevet ledsaget af en diskurs, der hele tiden opfordrer de unge til at være mere kreative og selvstændige, til at tænke selv og til at bryde med vaneforestillinger. For KKP's ledere er dette primært en pragmatisk beslutning drevet af økonomiske analyser, og de har næppe forestillet sig, at kreativiteten skal sprede sig uden for de felter, hvor man kan tjene penge på den. Men 
nogle af de unge har helt tydeligt taget opfordringen for pålydende og er begyndt at tænke sig selv ind i en ny sammenhæng, hvor de ikke blindt accepterer de rammer, der bliver stillet op for dem. De forventer sig et liv, hvor de har personlige rettigheder, hvor de selv kan træffe de afgørende beslutninger for deres tilværelse, og hvor de har lov til at stille spørgsmålstegn ved autoriteterne.

Denne mentale ændring sker i en social kontekst af stigende individualisering. De gamle institutioner, der bestemte, hvor man skulle bo og arbejde, er i opløsning, og der hersker en stemning af 'enhver er sin egen lykkes smed.'

Samtidig er familiemønstrene ved at ændre sig på grund af de små familiestørrelser og den øgede geografiske mobilitet, der spreder familiemedlemmer ud over hele landet på jagt efter arbejde eller uddannelse. De unge er stadig meget knyttede til deres familier, men de oplever, at deres væsentligste forpligtelse over for familien er at få succes i samfundet, også selv om det evt. betyder, at de kommer til at bo langt fra forældrene.

Hos de fleste af de unge, jeg talte med, var denne individualisering ledsaget af en stærk tiltrækning af vestlig ungdomskultur og af det langt mindre autoritære miljø, som de forestillede sig, at vestlige unge vokser op i. Klassisk demokratiseringsteori har hævdet en klar sammenhæng mellem økonomisk udvikling og demokratisering med middelklassen som den samfundsmæssige kraft, der på et tidspunkt vil begynde at kræve ændringer i det politiske system.

Hidtil har forskningen vist, at den kinesiske middelklasses interesse i demokratiske reformer er meget begrænset, men spørgsmålet er, om Kinas spring frem mod en mere innovativ økonomi kan skabe de ændringer i tankegangen, som den øgede velstand i sig selv endnu ikke har fremkaldt.

Sådanne spørgsmål er nok ikke noget, der umiddelbart vil holde de nye ledere vågne om natten, og sammenlignet med bekymringer om boligbobler, korruption, økonomisk afmatning og miljøkatastrofer er der da heller ingen grund til, at de skulle sætte dem øverst på deres dagsorden. Men på længere sigt kan det blive en afgørende udfordring for KKP at integrere en stadig mere selvstændigt tænkende generation i et autoritært system.

Stig Thøgersen er professor $i$ Kinastudier ved Aarhus Universitet. 